\title{
TARGETED, PRECISION IRRIGATION FOR MOVING PLATFORMS: SELECTED PAPERS FROM A CENTER PIVOT TECHNOLOGY TRANSFER EFFORT
}

\author{
F. R. Lamm, D. O. Porter, J. P. Bordovsky, S. R. Evett, S. A. O'Shaughnessy, \\ K. C. Stone, W. L. Kranz, D. H. Rogers, P. D. Colaizzi
}

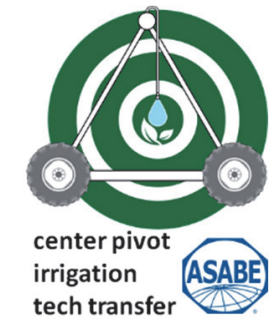

\section{Collection Introduction}

\section{HighLIGHTS}

- Center-pivot and lateral-move irrigation systems are used on over $85 \%$ of the irrigated area in the U.S. Great Plains.

- Low-energy precision application (LEPA) from mobile lateral irrigation platforms was first developed in 1978.

- Various in-canopy and near-canopy application technologies are widely practiced in the U.S. Great Plains.

- Adding advanced irrigation management technologies to moving platforms can optimize water and energy use.

- Uniformity of application is a key performance factor in evaluating moving irrigation platforms.

ABSTRACT. This article is an introduction to an ASABE Special Collection of ten articles concerning center pivot (CP) technology transfer that appears in this issue of Transactions of the ASABE and in Applied Engineering in Agriculture. The year 2018 marked the 40th anniversary of research and development of low-energy precision application (LEPA) for use with CP sprinkler irrigation systems. Since 1978, researchers, extension specialists, and industry have continued development of multiple technologies that are suitable for mobile lateral irrigation platforms. A two-year technology transfer effort with funding from the USDA-ARS Ogallala Aquifer Program (OAP) was initiated in January 2017 to promote adoption of advanced and efficient irrigation technologies and to highlight recommended practices for mobile irrigation platforms, including both CP and lateral-move (LM) systems. The articles in this Special Collection address five major topic areas: in-canopy and near-canopy irrigation application from moving platforms, site-specific variable-rate irrigation (VRI) and associated sensor technologies for moving platforms, the use of variable-frequency drives (VFDs) with CP systems, and uniformity evaluations for CP systems. While these ten articles are not inclusive of all the important advances in irrigation from moving platforms since 1978, they illustrate that continued improvement in irrigation management occurs by combining engineering and agronomic sciences. Pressurized irrigation from moving platforms is increasing in the U.S. and will be an important tool for meeting global food and water challenges. In addition to introducing and summarizing the Special Collection, this article provides additional rationale for the CP technology transfer effort. NonCommercial-NoDerivatives 4.0 International License https://creative commons.org/licenses/by-nc-nd/4.0/

Submitted for review in February 2019 as manuscript number NRES 13371; approved for publication as part of the Center-Pivot Irrigation Tech Transfer Collection by the Natural Resources \& Environmental Systems Community of ASABE in September 2019.

Mention of company or trade names is for description only and does not imply endorsement by the USDA. The USDA is an equal opportunity provider and employer.

The authors are Freddie R. Lamm, Professor and Research Irrigation Engineer, Northwest Research-Extension Center, Kansas State University, Colby, Kansas; Dana O. Porter, Professor and Extension Agricultural Engineer, Texas A\&M AgriLife Extension, Lubbock, Texas; James P. Bordovsky, Senior Research Scientist and Agricultural Engineer, Texas A\&M AgriLife Research, Plainview, Texas; Steven R. Evett, Research Soil Scientist, and Susan A. O'Shaughnessy, Research Agricultural Engineer, USDA-ARS Conservation and Production Research Laboratory, Bushland, Texas; Kenneth C. Stone, Research Agricultural Engineer, USDA-ARS Coastal Plains Soil, Water, and Plant Research Center, Florence, South Carolina; William L. Kranz, Professor and Extension Irrigation Engineer, Department of Biological Systems Engineering, University of Nebraska-Lincoln, Concord, Nebraska; Danny R. Rogers, Professor and Extension Agricultural Engineer, Department of Biological and Agricultural Engineering, Kansas State University, Manhattan, Kansas; Paul D. Colaizzi, Research Agricultural Engineer, USDA-ARS Conservation and Production Research Laboratory, Bushland, Texas. Corresponding author: Freddie R. Lamm, KSU Northwest ResearchExtension Center, P.O. Box 505, Colby, KS 67701; phone: 785-462-6281; email: flamm@ksu.edu.

Keywords. Center pivot, Irrigation uniformity, Lateral-move sprinkler, LEPA, Linear-move sprinkler, Low-energy precision application, Site-specific irrigation, Sprinkler irrigation, Variable-frequency drives, Variable-rate irrigation, VFD, VRI.

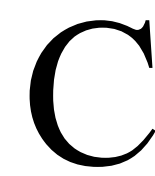

enter-pivot (CP) and lateral-move (LM) systems are currently the predominant irrigation methods in the U.S. (50\% of the land area, fig. 1). This is particularly the case in the U.S. Great Plains (fig. 2), which includes four of the top ten states in terms of irrigated area; an average of $85 \%$ of the irrigated area in those four states uses CP systems. The Kansas and Texas High Plains / Southern Ogallala Aquifer region, as part of the U.S. Great Plains, is noted for limited and declining groundwater resources (Konikow, 2013) and a relatively high adoption rate of efficient advanced irrigation technologies (Wagner, 2012; Colaizzi et al., 2009). One of the earliest advanced mobile sprinkler irrigation technologies, low- 


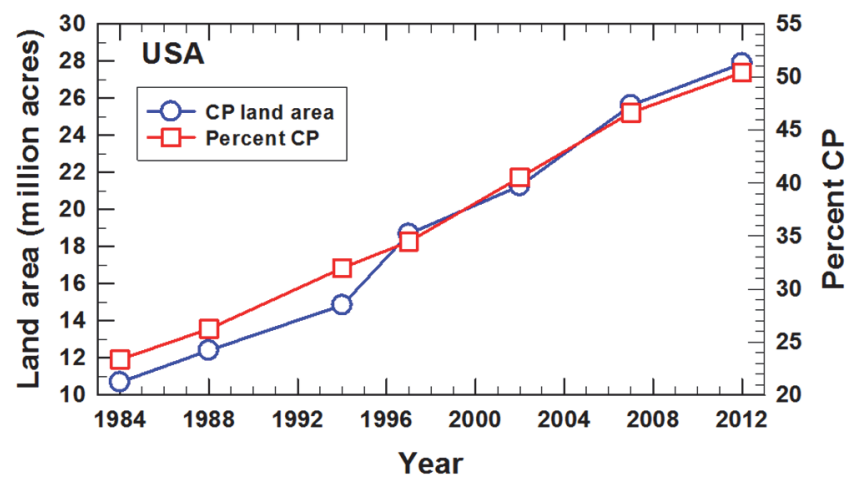

Figure 1. Time series (1984 to 2014) of the extent of center-pivot (CP) irrigation in the U.S. (data from USDA-NASS, 1984, 1988, 1994, 1998, 2002, 2008, and 2012).

energy precision application (LEPA), was first studied near Halfway, Texas, by William Lyle and James Bordovsky beginning in 1978 (Lyle and Bordovsky, 1981, 1983). Low-pressure CP irrigation, including (LEPA), low-elevation spray application (LESA), mid-elevation spray application (MESA), and other variations have become the most widely practiced irrigation methods in the region (Colaizzi et al., 2009). This is due in large part to the suitability of the technologies to the crop production systems in the region, relevant applied research programs, collaborations among research and extension programs and with industry, the effectiveness of cost-share programs, and the willingness of agricultural producers in the region to adopt technologies and best management practices (BMPs) to adapt to limited water conditions (Wagner, 2012). From the early work on LEPA that began in 1978, to LESA and MESA, and most recently to the new integrated sensor and control systems mounted on CP and LM systems, research and extension programs that are now affiliated with the USDA-ARS Ogallala Aquifer program (OAP) have made important contributions to the advancement of irrigation using mobile platforms.

While low-pressure CP irrigation is widely practiced in the U.S. Great Plains, applied research continues to refine the technologies and recommendations. Thus, a $\mathrm{CP}$ technology transfer effort was designed to provide opportunities for end-users to hear up-to-date recommendations to aid in their irrigation deci- sions. There is a need to improve understand-ing by non-practitioner audiences (e.g., absentee landlords, ag lenders, crop insurance agents, and policymakers) of the most appropriate uses of these technologies, so this CP technology transfer effort has helped to improve their understanding of the state of the art, considerations for irrigation management, and appreciation for the advances in irrigation technology, management, and efficiency. Additionally, the $\mathrm{CP}$ technology transfer effort provided an opportunity for engineers and scientists to collaborate and synthesize current knowledge into more accessible publications and media as well as to provide a venue to brainstorm additional improvements to systems and technologies.

In the spring of 2017, a broad range of U.S. irrigation engineers, scientists, USDA-NRCS specialists, and industry representatives associated with $\mathrm{CP}$ technologies were invited to participate in a brainstorming retreat sponsored by the OAP CP Technology Transfer Project held in Amarillo, Texas, on March 28-29. A total of 39 individuals from 16 U.S. states (Alabama, Arizona, California, Colorado, Georgia, Idaho, Kansas, Louisiana, Mississippi, Missouri, Nebraska, Oklahoma, Texas, South Carolina, South Dakota, and Virginia) participated in the retreat. The retreat's several goals included networking opportunities for both more-experienced and less-experienced individuals, electronic distribution of large bodies of CP-related publications from the Central Plains Irrigation Conference and the USDA-ARS Conservation and Production Research Laboratory, discussion of past and current research, identification of research, extension, and educational needs, and discussion of industry status and information gaps. Although it is impossible to fully capture the richness and value of this two-day event in this brief report, an attempt was made to tabulate the key topics, their status, and important knowledge gaps (table 1). No attempt to prioritize any of the topics was intended with this tabulation, nor should it be considered inclusive of all the topics discussed during the two-day event. The articles included this ASABE Special Collection address at least four of the issues listed in table 1 and are discussed in the following sections.

\section{IN-CANOPY AND NEAR-CANOPY IRRIGATION APPLICATION FROM MOVING PlatForms}

As table 1 suggests, there is much maturity in our under-

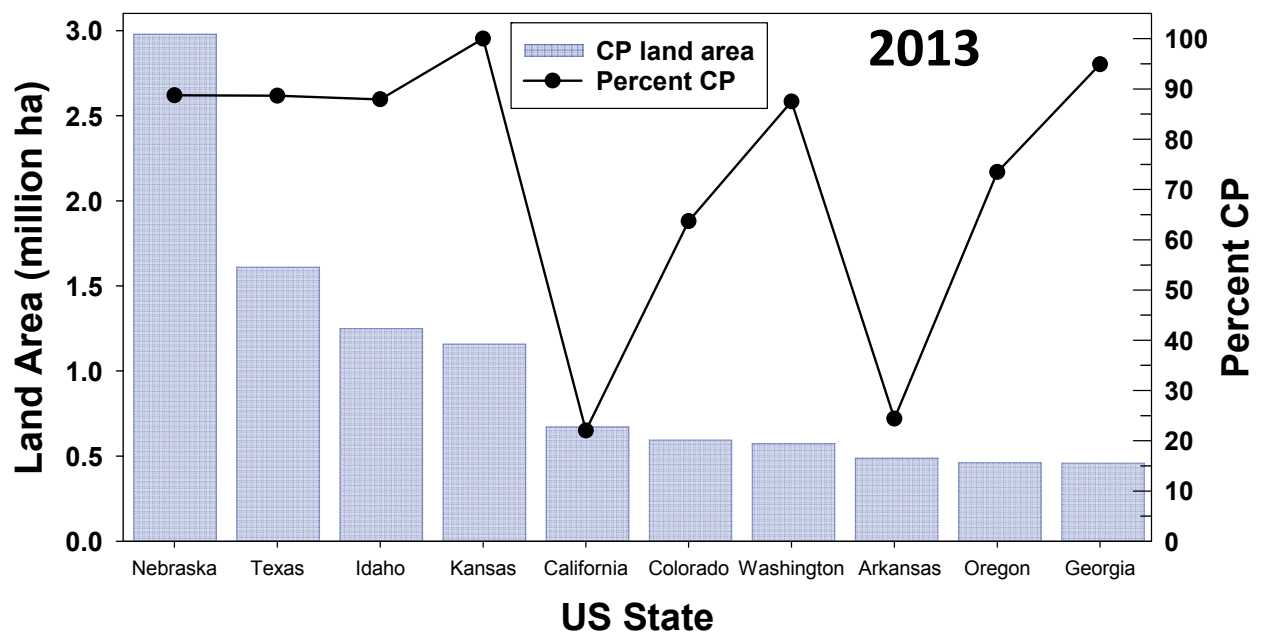

Figure 2. Extent of center-pivot irrigation in the ten U.S. states with the greatest areas of irrigation in 2013 (data from USDA-NASS, 2012). 
Table 1. Key topics, comments and information status, and knowledge and/or implementation gaps identified at a center-pivot irrigation brainstorming retreat in Amarillo, Texas, on 28-29 March 2017. This list is meant to portray the wide range of topics and some gaps that were identified. The order of this listing does not indicate priority, nor is it inclusive of all the ideas discussed during the two-day event.

\begin{tabular}{|c|c|c|}
\hline Topic & Comments and Information Status & Knowledge and/or Implementation Gaps \\
\hline $\begin{array}{c}\text { Variable-rate } \\
\text { irrigation (VRI) } \\
\text { and site-specific } \\
\text { irrigation (SSI) }\end{array}$ & $\begin{array}{l}\text { - Emerging technology, uncertainty remains about extent of future } \\
\text { needs and adoption. } \\
\text { - Three types identified (sector control, speed control, and VRI } \\
\text { zone or individual sprinkler control). } \\
\text { - Many current, commercially available CP systems have more ca- } \\
\text { pabilities than recognized by system end-users. } \\
\text { - VRI is not needed by all producers, and implementation is not } \\
\text { economically feasible for all operations. }\end{array}$ & $\begin{array}{l}\text { - Hardware development has outpaced development of management } \\
\text { information. } \\
\text { - Although many teams are working on dynamic prescriptions, con- } \\
\text { tinued work is needed to remove this impediment. } \\
\text { - Uncertainty about producer expectations. } \\
\text { - Abandonment can be high without appropriate support from indus- } \\
\text { try, universities, consultants, or USDA-NRCS. } \\
\text { - Continued need for research and education. }\end{array}$ \\
\hline $\begin{array}{l}\text { Sprinkler } \\
\text { packages and } \\
\text { application } \\
\text { systems }\end{array}$ & $\begin{array}{l}\text { - As a maturing technology, many different packages are provided } \\
\text { by industry to meet the needs of producers. } \\
\text { - Selection should consider crop, soil, water source and quality, } \\
\text { and energy. } \\
\text { - LEPA, LESA and MESA have specific requirements that need } \\
\text { consideration. } \\
\text { - Greater interest and adoption of in-canopy and near-canopy ap- } \\
\text { plication when evaporative losses are higher, irrigation capacity } \\
\text { is lower, and land slope is lower. }\end{array}$ & $\begin{array}{l}\text { - A maturing technology, but there are still many implementation } \\
\text { mistakes. } \\
\text { - "One size fits all" mentality ignores available knowledge. } \\
\text { - Runoff must be controlled first for any realistic success with in- } \\
\text { canopy and near-canopy sprinkler application. } \\
\text { - Educational needs of producers still remain. }\end{array}$ \\
\hline $\begin{array}{l}\text { Sprinkler } \\
\text { uniformity }\end{array}$ & $\begin{array}{l}\text { - Hydraulics can be modeled, but catch can results are still instruc- } \\
\text { tive and can point out hardware and implementation problems. } \\
\text { - Catch can tests are still time and labor intensive. } \\
\text { - Mismatch of nozzles and operating pressure is common. } \\
\text { - The crop can integrate some minor uniformity problems. }\end{array}$ & $\begin{array}{l}\text { - Uncertainty of continued status of some modeling efforts. } \\
\text { - CPED is now available from USDA-NRCS in a MS-Excel format. } \\
\text { - Producers still need to monitor and respond to the basic infor- } \\
\text { mation of system flow rate and pressure. }\end{array}$ \\
\hline $\begin{array}{l}\text { Mobile drip } \\
\text { irrigation }\end{array}$ & $\begin{array}{l}\text { - An emerging technology with just a few research studies to date. } \\
\text { - Can reduce wheel track problems (rutting). }\end{array}$ & $\begin{array}{l}\text { - Scope of appropriate applicability of the technology (e.g., soil } \\
\text { type, slope, crops) is still unknown. } \\
\text { - Rodents can be a problem. } \\
\text { - Forces applied on CP systems (structural loading) are of concern. } \\
\text { - Maintenance issues, filtration needs, and other concerns. } \\
\end{array}$ \\
\hline $\begin{array}{l}\text { Wheel tracks, } \\
\text { rutting, and } \\
\text { getting stuck }\end{array}$ & $\begin{array}{l}\text { - Primarily anecdotal or industry-held information. } \\
\text { - May negatively affect irrigation management, such as early end- } \\
\text { of-season irrigation termination. }\end{array}$ & $\begin{array}{l}\text { - Need for generic (non-brand specific) publication or guidance on } \\
\text { span selection and wheel/flotation system selection. }\end{array}$ \\
\hline Chemigation & $\begin{array}{l}\text { - A maturing technology, and perhaps not as much recent research } \\
\text { effort by the public sector and universities. } \\
\text { - Uncertainty of the audience (i.e., end-users, regulators, or chemi- } \\
\text { cal industry) may result in inertia. }\end{array}$ & $\begin{array}{l}\text { - Sprinkler packages and sprinkler spacings. } \\
\text { - VRI interactions with chemigation. } \\
\text { - Safety, industry standards, and associated education are needed. }\end{array}$ \\
\hline $\begin{array}{l}\text { Microbursts, } \\
\text { tornadoes, and } \\
\text { center pivots }\end{array}$ & $\begin{array}{l}\text { - No known information resources identified. } \\
\text { - Could this be a student project or modeling effort? }\end{array}$ & $\begin{array}{l}\text { - What direction to park } \mathrm{CP} \text { to reduce risk of damage? } \\
\text { - Loaded with water for downforce or not? }\end{array}$ \\
\hline $\begin{array}{l}\text { Center pivot } \\
\text { safety }\end{array}$ & $\begin{array}{l}\text { - A maturing knowledge base. } \\
\text { - USDA-NRCS has some materials and trains its own staff about } \\
\text { safety concerns with CP systems. }\end{array}$ & $\begin{array}{l}\text { - Producers and installers still need education. } \\
\text { - Need for lay-oriented publications. } \\
\text { - Who has expertise for presentations? }\end{array}$ \\
\hline $\begin{array}{l}\text { Remote } \\
\text { sensing }\end{array}$ & $\begin{array}{l}\text { - An emerging area with large amount of interest. } \\
\text { - Can interface with VRI research needs and with standalone re- } \\
\text { search as well. } \\
\text { - UAVs are of considerable interest to producers. } \\
\text { - Remote sensing could encompass weather, soil, or plant infor- } \\
\text { mation and combinations of the three types. } \\
\end{array}$ & $\begin{array}{l}\text { - Many approaches are necessary for research, but the large number } \\
\text { of options makes selecting an approach difficult for producers. } \\
\text { - Hardware offerings may outpace development of management in- } \\
\text { formation. } \\
\text { - Continued need for research and education. }\end{array}$ \\
\hline $\begin{array}{l}\text { Variable-frequency } \\
\text { drives (VFDs) }\end{array}$ & $\begin{array}{l}\text { - The technology is maturing and interest is growing due to wider } \\
\text { use of electricity as the sole energy source for CPs. } \\
\text { - Still not economical for many cases. } \\
\text { - Economic feasibility depends on field slopes and changes in pres- } \\
\text { sures, time of operation, and price of energy. }\end{array}$ & $\begin{array}{l}\text { - Some evaluations have been done in the region, but more are } \\
\text { needed. } \\
\text { - More modeling is needed. } \\
\text { - VRI will further complicate the need for VFDs }\end{array}$ \\
\hline $\begin{array}{l}\text { Publications } \\
\text { and information } \\
\text { needs }\end{array}$ & $\begin{array}{l}\text { - Mature, yet continuing evolving topic area. } \\
\text { - Fewer attendees at traditional university-led workshops, tours, } \\
\text { and field days. } \\
\text { - Not just an agricultural problem, based on attendance, and land- } \\
\text { scape management has similar issues. } \\
\text { - Grower panels can be useful when sufficiently unbiased and sci- } \\
\text { entifically sound. } \\
\text { - Younger audiences are more open to electronic media. } \\
\text { - Fewer, better, regional conferences may be an option for sound- } \\
\text { ing the knowledge but may still have attendance issues. }\end{array}$ & $\begin{array}{l}\text { - How well are we targeting audiences? } \\
\text { - Do we adjust to the audience (i.e., professionals, producers, regu- } \\
\text { lators, industry, legislators, urban, gender, and age)? } \\
\text { - Could public/private partnerships be used to greater advantage? } \\
\text { - Individual companies may have material that could be packaged } \\
\text { for industrywide education. } \\
\text { - Technology farms or large-plot research may be better for infor- } \\
\text { mation delivery. }\end{array}$ \\
\hline $\begin{array}{l}\text { University } \\
\text { degree programs } \\
\text { and certificate } \\
\text { programs }\end{array}$ & $\begin{array}{l}\text { - Small and decreasing numbers of agricultural irrigation programs } \\
\text { in the U.S. are attracting fewer U.S.-born students. } \\
\text { - The importance of agriculture is not always reflected. } \\
\text { - Community colleges may be able to fill some staffing needs. } \\
\text { - USDA-NIFA may be helpful in providing irrigation fellowships } \\
\text { to help build capacity. }\end{array}$ & $\begin{array}{l}\text { - Industry needs well-educated staff who are willing to live in agri- } \\
\text { cultural regions. } \\
\text { - Universities need well-trained faculty and funding to retain good } \\
\text { faculty. } \\
\text { - Universities need to develop students to find food and fiber solu- } \\
\text { tions for } 9.6 \text { billion people by } 2050 \text {. }\end{array}$ \\
\hline
\end{tabular}


standing of sprinkler packages, application systems, and their appropriate application, but there are still major gaps in the implementation by end-users. Efforts are warranted to improve education of end-users of the conceptual requirements of these systems and to point out operation-specific applicability (i.e., where these systems may work, and where they may not work).

The original development of LEPA coincided with a period of relatively high energy costs and concerns about energy availability in the late 1970s; thus, low energy use was a key objective of LEPA development. In Texas, where LEPA was originally developed in semi-arid conditions, air and canopy evaporative losses from sprinkler irrigation can be appreciable, reducing crop yields in water-limited operations with low-capacity irrigation systems, so reduction or elimination of these losses was an advantage of LEPA. Scientifically, LEPA has always been considered to be a system of technologies, with both CP hardware and adoption of specific farming practices (Lyle, 1992). The required elements of LEPA irrigation systems are discussed in a Special Collection article by Bordovsky (2019) that provides a fortyyear review of LEPA. In addition to discussing the required elements for successful LEPA, this article discusses the historical development and efforts to establish design and operating criteria. A considerable amount of early research was concentrated on design and operating criteria, such as applicator spacing, irrigation intervals, and irrigation amounts. Research results for LEPA on various crops are also presented, along with comparisons of LEPA with other irrigation systems. As continued progress was made with LEPA, research conducted at Texas A\&M University examined possibilities for using LEPA as a platform for more complex systems or operations, such as application of chemicals within crop canopies or planting crops by incorporating seeds into the irrigation stream before the LEPA applicator (Bordovsky, 2019). LEPA continues to be an important water conservation tool that provides an energy-efficient and economical method of irrigating row crops. Industry has also promoted its adoption through development of brand-specific applicators. As far back as 1998, the worldwide annual economic benefit of LEPA was estimated to be greater than USD \$1.1 billion (Lacewell, 1998).

Following the development of LEPA, other low-pressure in-canopy and near-canopy sprinkler application technologies were developed, such as LESA, MESA, low-pressure in-canopy (LPIC), LEPA with drag sock, and precision application residue managed (PARM). A Special Collection review article by Lamm et al. (2019) discusses in-canopy and near-canopy sprinkler application. The authors list seven guiding principles for LEPA, provided by Lyle (1992), and focus a considerable portion of their article on the need to match the guiding principle that all plants should have equal opportunity to the applied irrigation water. They discuss how partitioning of the sprinkler irrigation amount in fully developed corn canopies is affected by sprinkler type and corn row location. Symmetry of sprinkler application, spatial orientation of the sprinklers with respect to the corn rows, and the seasonal duration of the sprinkler pattern distortion are all concluded to be important factors in plants achieving equal opportunity to the applied water. One of the reasons that producers are interested in LEPA and other low-pressure systems is to reduce evaporative losses. However, because the wetting patterns for these systems are much smaller than for impact sprinklers, runoff losses can easily surpass any reductions in evaporative losses. Runoff and surface water redistribution are also discussed by Lamm et al. (2019), with research and anecdotal results indicating their potential magnitude and consequences.

In a Special Collection article by Evett et al. (2019), MESA and subsurface drip irrigation (SDI) are compared for corn and grain sorghum production in the Texas Panhandle in terms of measured crop evapotranspiration using large weighing lysimeters, grain yield, and water use efficiency (WUE, defined as yield divided by crop water use). Evaporative losses were generally less with SDI than with MESA, particularly in the early season before the crop canopy covered the soil surface and during any preplant irrigation when the soil was bare. Differences were greater for corn than for grain sorghum. Evaporative differences became smaller as the plant height increased, suggesting that LEPA or LESA could further decrease sprinkler evaporative losses in this semi-arid region. Corn grain yield was up to $19 \%$ greater with SDI compared to MESA in two separate years, while sorghum yields were equal to or $15 \%$ less with SDI in two other years. WUE was greater with SDI in both years for corn but only in one year for grain sorghum. Evett et al. (2019) conclude that SDI would be successful for corn production, but that MESA might be preferable to SDI for grain sorghum. Similarly, grain yield for grain sorghum was greater with LEPA than with SDI in northwest Kansas with irrigation regimes designed to replace $60 \%, 80 \%$, or $100 \%$ of ET minus rainfall (Lamm et al., 2010). Increased WUE with SDI is one reason why SDI has become a significant technology in west Texas, despite its greater capital cost compared with CP.

Briefly summarized, the science and conceptualization of low-pressure CP irrigation technologies has led to multiple adaptations of the technology that have been adopted on a wide scale in the U.S. Great Plains and are beginning to be adopted in other areas. However, when the implementation knowledge gained in earlier studies is ignored or discarded, much of the potential water and energy savings is not realized.

\section{SITE-SPECIFIC VARIABLE-RATE IRRIGATION AND ASSOCIATED SENSOR TECHNOLOGIES}

Site-specific VRI was identified as an important emerging topic in the U.S. in the 2017 CP technology brainstorming retreat discussed earlier (table 1), and the consensus was that hardware development has often outpaced the development of management information. Special Collection articles addressing site-specific VRI for CP systems and associated sensors for monitoring and/or control are provided by Colaizzi et al. (2019), O'Shaughnessy et al. (2019a, b), and Stone et al. (2019).

A current review of the advantages and disadvantages of VRI is the focus of O'Shaughnessy et al. (2019a). The listed advantages focus on economic, environmental, and agronomic aspects generally related to greater productivity and efficiency resulting from improved resource management 
while enhancing risk management. The listed disadvantages concern the high upfront costs when additional VRI hardware is required and the complexity of management and risk, particularly in the case of matching VRI to variable spatiotemporal crop needs within the field. The authors conclude that a number of advances have occurred in recent years to further develop VRI, and that multiple teams across the U.S. are taking multiple approaches to address VRI management. The authors propose a design protocol for a VRI system that includes delineation of management zones (i.e., geographical representation of homogenous managed areas), addressing both spatial and temporal variability in plant water status through information from sensor networks, establishing fundamental irrigation management rules for VRI, and recognizing that VRI requires timely updating of robust prescription maps frequently during the crop season. Although the current number of VRI systems in the U.S. is small, this number is anticipated to increase, and those working in the VRI area will need to identify where VRI can be beneficial and where it will likely not be beneficial.

Inherent to successful VRI application is the ability to monitor crop status in real-time or near real-time to allow dynamic updating of prescriptive irrigation schemes. In a Special Collection article by Colaizzi et al. (2019), a comparison of stationary and moving (i.e., onboard CP) infrared thermometer (IRT) measurements is discussed. The authors found that temperature measurement errors and noise were generally similar between moving and stationary platforms and that addition of more expensive hardware to decrease errors due to CP movement does not appear justified. They indicate that the addition of low-cost imaging radiometers might improve the interpretation of IRT temperature measurements.

In a Special Collection article by Stone et al. (2019), the potential for water conservation with site-specific VRI is examined through simulation modeling. Water requirements for a highly variable field site (Sadler et al., 2002) with 12 soil mapping units were simulated over a 21 -year period under irrigation scenarios consisting of various numbers of management zones with either fixed $12.5 \mathrm{~mm}$ irrigation events or full irrigation replacement to field capacity. The authors conclude that VRI design should not be based entirely on the average weather conditions and that greater VRI effectiveness can be obtained by identifying management zones based on actual or anticipated weather conditions. They point out that VRI, as compared to uniform irrigation, can either increase or decrease the total amount of irrigation water required for adequate irrigation, depending on the different management zones within the field. This may be instructive for understanding why there have been mixed results when assessing water savings under VRI and why water use efficiency, rather than water saving, may be the key point of VRI.

Current marketing of drought-tolerant (DT) corn hybrids has generally focused on developing hybrids that can tolerate moderate levels of plant water stress and sustain grain yield, without suffering yield suppression when conditions are favorable for high grain yield. Generally, this requires development of hybrids specific to a target region with its inherent climatic conditions. A Special Collection article by
O'Shaughnessy et al. (2019b) examines the productivity of DT hybrids at varying levels of irrigation in the semi-arid Texas High Plains. The authors report a greater grain yield for a 101-day early-maturity DT hybrid than for a 96-day early-maturity DT hybrid when seasonal crop water use exceeded approximately $675 \mathrm{~mm}$, but the 96-day early-maturity DT hybrid had greater yields for lower crop water use. In a drier year, the authors found that a 115-day mediummaturity DT hybrid compared to a 101-day early-maturity hybrid had greater yield and greater yield response to seasonal crop water use. Summarizing additional years of studies with both conventional and DT hybrids, they conclude that current DT hybrids have greater yields than previous older conventional hybrids and have yields similar to today's conventional hybrids in the Texas High Plains. When corn was severely deficit-irrigated, the DT hybrid response was not improved over conventional hybrids. These data suggest that corn hybrid selection will remain an important factor for both deficit irrigation and VRI scenarios.

\section{VARIABLE-FREQUENCY DRIVES WITH CP IRRIGATION SYSTEMS}

The addition of an end gun (i.e., a large sprinkler attached to the lateral distal end) or a corner extension allows a circular CP system to irrigate a greater proportion of a square field. However, these systems increase the complexity of $\mathrm{CP}$ operation and management, and they require the capability to manage power requirements due to the changing flow rates and pressure. Additionally, large elevation changes within CP irrigated fields can affect power requirements. VFDs are a new technology in irrigated agriculture that increase and decrease the speed of electric pump motors. VFDs can help manage the changing flow rates and pressure for CP systems. A Special Collection article by Brar et al. (2019) discusses the potential for energy conservation and economic benefits with VFDs by simulating VFD use on $1,000 \mathrm{CP}$ systems in ten counties across Nebraska. The authors found that the resulting energy savings and net returns were greatly influenced by topographical changes within the CP field, the characteristics of the corner attachment operation, and the electrical energy costs. In some cases, although energy savings were achieved, the payback period for the VFD exceeded its expected life. The results illustrate realistic scenarios in which VFDs can have a positive effect.

\section{UNIFORMITY EVALUATIONS FOR CP IRRIGATION SYSTEMS}

Sprinkler application uniformity was also an important topic discussed at the $2017 \mathrm{CP}$ brainstorming retreat (table 1) and is the subject of two Special Collection articles by Rogers et al. (2019a, b). Catch can diameter and placement can have an effect on spray catch and on the resulting uniformity values for some newer sprinkler applicators (e.g., fixed, spinning, or wobbling plate), as discussed by Rogers et al. (2019a). The authors compared four collector diameters $(55,100,147.5$, and $200 \mathrm{~mm})$ using a Latin-square study design. To minimize catch variability, they recommend 100 or $147.5 \mathrm{~mm}$ catch cans for spinning plate sprinklers, but the can size is less important for the other types of sprinklers. Increasing the number of collectors to five to ten in a partic- 
ular measurement area decreased the variability to less than $5 \%$ for all sprinkler applicators. These results add value to an earlier study by O'Shaughnessy et al. (2013) of wind effects on irrigation distribution across and between VRI zones managed to apply different amounts of water. The earlier study found that the orientation and pattern of $200 \mathrm{~mm}$ catch cans, along with a mechanism for catch can leveling, were important for accurately assessing wind effects on VRI distribution.

A series of CP uniformity evaluations on fields in Kansas is the subject of a Special Collection article by Rogers et al. (2019b) The 53 tests were conducted over multiple years to provide information about the typical performance of $\mathrm{CP}$ sprinkler packages on Kansas farms, although the systems were not randomly selected but rather were selected according to voluntary participation in the program. The average Christiansen uniformity coefficient with the Heermann-Hein modification $\left(\mathrm{CU}_{\mathrm{HH}}\right)$ for all tested systems was 79 , with a range from 53 to 92 . Early tests tended to be on producer fields participating in a demonstration project and tended to have higher $\mathrm{CU}_{\mathrm{HH}}$ values, which indicates that good values are achievable. Later tests, conducted at the request of producers, tended to be for systems suspected of having uniformity problems. Many of the sprinkler package deficiencies could have been identified and corrected with visual inspection and/or a comparison to the design specifications. Information from these tests has been used in meetings and publications to inform producers of the importance of uniformity and sprinkler package design, installation, and maintenance. Further work summarized by Rogers et al. (2019a) examined the effect of collector size on catch amount and variability. In general, collector sizes of $10 \mathrm{~cm}$ or greater did not substantially affect accuracy, as long as a sufficient number of collectors was used.

\section{Concluding Statements}

Some CP technologies are relatively mature and have a rich and robust knowledge base, but it is important to periodically review the history and conceptual requirements that brought about and constrain these technologies. This is particularly important as efforts are made to extend these technologies into new regions or new circumstances with differing constraints. The Special Collection articles by Bordovsky (2019) and Lamm et al. (2019) focus on providing such reviews, while Evett et al. (2019) compares a low-pressure CP application system to subsurface drip irrigation.

Other CP technologies can be categorized as emerging and represent promising opportunities to advance targeted, precision irrigation, such as site-specific VRI and associated sensor technologies, which are the subject of four Special Collection articles (Colaizzi et al., 2019; O'Shaughnessy et al., 2019a, b; Stone et al., 2019). These articles present important information for characterizing and monitoring VRI and discuss how VRI technologies must also consider additional factors, such as weather, plant water stress information, and cultivar characteristics.

The use of VFDs was the focus of a large simulation study for 1,000 CP systems across Nebraska in a Special Collection article by Brar et al. (2019). Their results suggest that this emerging technology can result in energy savings and economic benefits, but the benefits greatly depend on field topography, CP characteristics, and operation.

Although CP sprinkler application uniformity has a mature knowledge base, producers still have difficulty implementing or maintaining uniform designs in commercial settings. Catch can tests, as discussed in Special Collection articles by Rogers et al. (2019a, b), are an important tool for documenting the uniformity of both effective and ineffective sprinkler designs and for encouraging producers to improve their CP sprinkler uniformity.

This Special Collection is not an exhaustive discussion of the needs for CP technology transfer but rather a part of the continuing effort to help practitioners use and advance targeted, precision irrigation from moving platforms. Emerging public policy, along with declining aquifers, improved technologies, and changing climate, will continue to play an important role in the future of irrigation practices and the importance of continued technology transfer.

\section{ACKNOWLEDGEMENTS}

This article is part of a CP irrigation technology transfer effort supported by the Ogallala Aquifer Program, a consortium of the USDA-ARS, Kansas State University, Texas A\&M AgriLife Research, Texas A\&M AgriLife Extension Service, Texas Tech University, and West Texas A\&M University. Contribution No. 19-224-J from the Kansas Agricultural Experiment Station. Some of the research reported here was supported by the USDA National Institute of Food and Agriculture under Award Nos. 2016-67021-24420 and 2016-68007-25066.

\section{REFERENCES}

Bordovsky, J. P. (2019). Low-energy precision application (LEPA) irrigation: A forty-year review. Trans. ASABE, 62(5). https://doi.org/10.13031/trans.13117

Brar, D., Kranz, W. L., Lo, T., Irmak, S., \& Martin, D. L. (2019). Energy conservation using variable-frequency drives for centerpivot irrigation systems equipped with corner watering attachments. Trans. ASABE, 62(5). https://doi.org/10.13031/trans.13312

Colaizzi, P. D., Gowda, P. H., Marek, T. H., \& Porter, D. O. (2009). Irrigation in the Texas High Plains: A brief history and potential reductions in demand. Irrig. Drain., 58(3), 257-274. https://doi.org/10.1002/ird.418

Colaizzi, P. D., O'Shaughnessy, S. A., Evett, S. R., \& Andrade, M. A. (2019). Comparison of stationary and moving infrared thermometer measurements aboard a center pivot. Appl. Eng. Agric., 35(6), in press. https://doi.org/10.13031/aea.13443

Evett, S. R., Marek, G. W., Colaizzi, P. D., Brauer, D. K., \& O'Shaughnessy, S. A. (2019). Corn and sorghum ET, E, yield, and CWP affected by irrigation application method: SDI versus mid-elevation spray irrigation. Trans. ASABE, 62(5). https://doi.org/10.13031/trans.13314

Konikow, L. F. (2013). Groundwater depletion in the United States (1900-2008). USGS Scientific Investigations Report 2013-5079. Reston, VA: USGS. https://doi.org/10.3133/sir20135079

Lacewell, R. D. (1998). Precision agriculture and value of water. Proc. Great Plains Symp. Determining the Value of Water (pp. 
46-50). Great Plains Foundation.

Lamm, F. R., Bordovsky, J. P., \& Howell Sr., T. A. (2019). A review of in-canopy and near-canopy sprinkler irrigation concepts. Trans. ASABE, 62(5). https://doi.org/10.13031/trans.13229

Lamm, F. R., Colaizzi, P. D., Bordovsky, J. P., Trooien, T. P., Enciso-Medina, J., Porter, D. O.,... O'Brien, D. M. (2010). Can subsurface drip irrigation (SDI) be a competitive irrigation system in the Great Plains region for commodity crops? ASABE Paper No. IRR109686. St. Joseph, MI: ASABE.

Lyle, W. M. (1992). LEPA, concept and system. Proc. Central Plains Irrigation Short Course (pp. 14-16). Central Plains Irrigation Association.

Lyle, W. M., \& Bordovsky, J. P. (1981). Low Energy Precision Application (LEPA) irrigation system. Trans. ASAE, 24(5), 1241-1245. https://doi.org/10.13031/2013.34427

Lyle, W. M., \& Bordovsky, J. P. (1983). LEPA irrigation system evaluation. Trans. ASAE, 26(3), 776-781. https://doi.org/10.13031/2013.34022

O’Shaughnessy, S. A., Evett, S. R., Colaizzi, P. D., Andrade, M. A., Marek, T. H., Heeren, D. M.,... LaRue, J. L. (2019a). Identifying advantages and disadvantages of variable-rate irrigation: An updated review. Appl. Eng. Agric., 35(6), in press. https://doi.org/10.13031/aea.13128

O’Shaughnessy, S. A., Kim, M., Andrade, M. A., Colaizzi, P. D., \& Evett, S. R. (2019b). Response of drought-tolerant corn to varying irrigation levels in the Texas High Plains. Trans. ASABE, 62(5). https://doi.org/10.13031/trans.13234

O’Shaughnessy, S. A., Urrego, Y. F., Evett, S. R., Colaizzi, P. D., \& Howell, T. A. (2013). Assessing application uniformity of a variable rate irrigation system in a windy location. Appl. Eng. Agric., 29(4), 497-510. https://doi.org/http://dx.doi.org/10.13031/aea.29.9931

Rogers, D. H., Aguilar, J., Clark, G. A., \& Wiens, S. W. (2019a). Effect of collector size on center pivot water depth catch. Appl.
Eng. Agric., 35(6), in press. https://doi.org/10.13031/aea.13311

Rogers, D. H., Aguilar, J., \& Sharda, V. (2019b). Kansas center pivot uniformity evaluation overview. Appl. Eng. Agric., 35(6), in press. https://doi.org/10.13031/aea.13335

Sadler, E. J., Camp, C. R., Evans, D. E., \& Millen, J. A. (2002). Spatial variation of corn response to irrigation. Trans. ASAE, 45(6), 1869-1881. https://doi.org/10.13031/2013.11438

Stone, K. C., Bauer, P. J., \& Sigua, G. C. (2019). Potential water conservation using site-specific variable-rate irrigation. Appl. Eng. Agric., 35(6), in press. https://doi.org/10.13031/aea.13108

USDA-NASS. (1984). Farm and ranch irrigation survey. Washington, DC: USDA-NASS. Retrieved from www.agcensus.usda.gov.

USDA-NASS. (1988). Farm and ranch irrigation survey. Washington, DC: USDA-NASS. Retrieved from www.agcensus.usda.gov.

USDA-NASS. (1994). Farm and ranch irrigation survey. Washington, DC: USDA-NASS. Retrieved from www.agcensus.usda.gov.

USDA-NASS. (1998). Farm and ranch irrigation survey. Washington, DC: USDA-NASS. Retrieved from www.agcensus.usda.gov.

USDA-NASS. (2002). Farm and ranch irrigation survey. Washington, DC: USDA-NASS. Retrieved from www.agcensus.usda.gov.

USDA-NASS. (2008). Farm and ranch irrigation survey. Washington, DC: USDA-NASS. Retrieved from www.agcensus.usda.gov.

USDA-NASS. (2012). Farm and ranch irrigation survey. Washington, DC: USDA-NASS. Retrieved from www.agcensus.usda.gov.

Wagner, K. (2012). Status and trends of irrigated agriculture in Texas. Special Report TWRI EM-115. College Station: Texas Water Resources Institute. Retrieved from https://twri.tamu.edu/media/2525/em-115_irrigatedag.pdf 